\title{
Digital Nudging
}

\author{
Markus Weinmann · Christoph Schneider • \\ Jan vom Brocke
}

Received: 21 October 2015/ Accepted: 5 August 2016/Published online: 3 October 2016

(c) The Author(s) 2016. This article is published with open access at Springerlink.com

Keywords Nudging · Information systems design · Human-computer interaction - Online choice architecture

\section{Digital Nudging - Guiding Judgment and Decision-Making in Digital Choice Environments}

Digital nudging is the use of user-interface design elements to guide people's behavior in digital choice environments. Digital choice environments are user interfaces - such as web-based forms and ERP screens - that require people to make judgments or decisions. Humans face choices every day, but the outcome of any choice is influenced not only by rational deliberations of the available options but also by the design of the choice environment in which information is presented, which can exert a subconscious influence on the outcome. In other words, "what is chosen often depends upon how the choice is presented" (Johnson et al. 2012, p. 488) such that the "choice architecture alters people's behavior in a predictable way" (Thaler and Sunstein 2008, p. 6). Even simple modifications of the choice environment in which options are presented can

Accepted after one revision by Prof. Dr. Sinz.

Dr. M. Weinmann $(\bowtie) \cdot$ Prof. Dr. J. v. Brocke

Institute of Information Systems, University of Liechtenstein,

Fürst-Franz-Josef-Strasse, 9490 Vaduz, Liechtenstein

e-mail: markus.weinmann@uni.li

Prof. Dr. J. v. Brocke

e-mail: jan.vom.brocke@uni.li

Dr. C. Schneider

Department of Information Systems, City University of Hong

Kong, 83 Tat Chee Avenue, Kowloon, Hong Kong

e-mail: christoph.schneider@cityu.edu.hk influence people's choices and "nudge" them into behaving in particular ways. In fact, there is no neutral way to present choices. For example, Johnson and Goldstein (2003) showed that simply changing default options (from opt-in to opt-out) in the context of organ donation nearly doubled the percentage of people who consent to being organ donors.

Many choices are made in online environments. As the design of digital choice environments always (either deliberately or accidentally) influences people's choices, understanding the effects of digital nudges in these environments can help designers lead users to the most desirable choice. For example, the mobile payment app Square nudges people into giving tips by setting the default to "tipping" so that customers must actively select a "no tipping" option if they choose not to give a tip. Using this simple nudge has raised tip amounts, especially where little or no tipping has been common (Carr 2013). These examples show that simply changing the default option affects the outcome.

\section{Relevance}

The increasing use of digital technologies in large areas of our private and professional lives means that people frequently make important decisions within digital choice environments. Most, if not all, online interactions - ranging from e-government to e-commerce interactions - require people to make choices.

User interfaces such as Web sites and mobile apps frequently include digital choice environments; likewise, interfaces of organizational information systems such as ERP and CRM systems are digital choice environments that predefine or influence decisions by how the system 
organizes and presents workflows. Since there is no neutral way to present choices, all decisions related to user-interface design influence users' behavior (Mandel and Johnson 2002; Sunstein 2015), often regardless of the designers' intent. A digital choice environment's design that accidentally influences people's choices may lead to unintended consequences; therefore, designers must understand the effects of their designs on users' choices so they can choose whether to implement a design that nudges users deliberately or one that reduces the effects of the design on users' choices in order to increase free will.

A key consideration when making such design decisions is the ethical implications of using nudges. While nudges should be used to help people make better choices (Thaler and Sunstein 2008), this is not always the case in practice. For example, some European low-cost air carriers present choices of non-essential options in a way that nudges customers toward purchasing these options. While these unethical nudges may lead to short term gains for the company, they may have long-term repercussions in terms of loss of goodwill, negative publicity, or even legal action. Therefore, designers must be aware of the ethical implications of nudges (see Sunstein 2015 for a discussion of nudging ethics).

\section{Current Status}

Research on nudging has been conducted primarily in offline contexts. Whereas traditional economic theory suggests that human behavior is rational, nudging works because people do not always behave rationally. In particular, research in psychology has demonstrated that, because of their cognitive limitations, people act in boundedly rational ways (Simon 1955), and various heuristics and biases influence their decision-making (Tversky and Kahneman 1974). Heuristics, commonly defined as simple "rules of thumb" (Hutchinson and Gigerenzer 2005, p. 98) that people use to ease their cognitive load in making judgments or decisions, can influence decision-making positively or negatively: They can be helpful in making simple, recurrent decisions by reducing the amount of information to be processed so people can focus on differentiated factors (Evans 2006), reducing mental effort (Evans 2008). On the other hand, heuristic thinking can result in cognitive biases and introduce systematic errors when making complex judgments or decisions (Tversky and Kahneman 1974) that require effortful thinking (Evans 2006). In such situations, common heuristics - such as the anchoring and adjustment heuristic (e.g., using the default values), the availability heuristic (e.g., being influenced by the vividness of events), and the representativeness heuristic (i.e., relying on stereotypes)
(Tversky and Kahneman 1974) - affect the evaluation of alternatives, often leading to suboptimal decisions.

Nudges attempt either to counter or to encourage the use of heuristics by altering the choice environment to change people's behavior. Commonly used nudges include giving incentives, providing feedback or anchors, and setting defaults (Dolan et al. 2012; Johnson et al. 2012; Michie et al. 2013; Thaler and Sunstein 2008; see Table 1).

In various situations, the designers of the choice environments (sometimes referred to as "choice architects"; Thaler et al. 2010, p. 1) attempt to influence people's choices. For example, many organizations encourage people to engage in socially responsible behaviors, such as leading a healthy life (e-health; e.g., the Fitbit provides feedback on physical activity), reducing waste or energy consumption (Green IS; e.g., Nest thermostats provide feedback on energy consumption), and planning for retirement (e-finance; e.g., governments set defaults on retirement options). Likewise, many non-governmental organizations attempt to encourage people to donate funds, participate in charitable activities, or vote for particular outcomes. In an e-commerce context, Web sites often use opt-in or opt-out mechanisms to nudge users into signing up for newsletters.

\section{Applications of Digital Nudging and Future Trends}

\subsection{Applications}

By definition, digital nudging focuses on guiding the behavior of individuals, but the effects of digitally nudging individuals can extend to organizational or societal levels (see Table 2).

While digital nudging, as described in this article, focuses on people's choices in digital choice environments, the concept can be applied beyond this context, as nudges in digital environments are increasingly used to influence realworld behavior. One example is the Fitbit activity monitor, where digital nudges (e.g., reminding the user to exercise, giving feedback on activity, presenting friends' statistics) are used to nudge people into increasing their activity levels.

\subsection{Future Trends}

Digital nudging will have a significant impact on future information systems research and practice, particularly for design-oriented information systems research. As user interfaces will always steer people in certain directions (depending on how information is presented), information systems designers must understand the behavioral effects of interface design elements so that digital nudging does not happen at random and unintended effects do not occur. 
Table 1 Selection of nudge principles, descriptions, and examples (based on Thaler et al. 2010)

\begin{tabular}{|c|c|c|}
\hline $\begin{array}{l}\text { Nudge } \\
\text { principle }\end{array}$ & Description & Example \\
\hline Incentive & $\begin{array}{l}\text { Making incentives more salient to increase their } \\
\text { effectiveness }\end{array}$ & $\begin{array}{l}\text { Telephones that are programmed to display the running cost of phone } \\
\text { calls }\end{array}$ \\
\hline $\begin{array}{l}\text { Understanding } \\
\text { mapping }\end{array}$ & $\begin{array}{l}\text { Mapping information that is difficult to evaluate to } \\
\text { familiar evaluation schemes }\end{array}$ & $\begin{array}{l}\text { Mapping megapixels to maximum printable size instead of pointing to } \\
\text { megapixels when advertising a digital camera }\end{array}$ \\
\hline Defaults & Preselecting options by setting default options & $\begin{array}{l}\text { Changing defaults (from opt-in to opt-out) to increase the percentage } \\
\text { of people who consent to being organ donors }\end{array}$ \\
\hline $\begin{array}{l}\text { Giving } \\
\text { feedback }\end{array}$ & $\begin{array}{l}\text { Providing users with feedback when they are doing } \\
\text { well or making mistakes }\end{array}$ & $\begin{array}{l}\text { Electronic road signs with smiling or sad faces depending on the } \\
\text { vehicle's speed }\end{array}$ \\
\hline $\begin{array}{l}\text { Expecting } \\
\text { error }\end{array}$ & $\begin{array}{l}\text { Expecting users to make errors and being as } \\
\text { forgiving as possible }\end{array}$ & $\begin{array}{l}\text { Requiring people at an ATM to retrieve the card before they receive } \\
\text { their money in order to help them avoid forgetting the card }\end{array}$ \\
\hline $\begin{array}{l}\text { Structure } \\
\text { complex } \\
\text { choices }\end{array}$ & $\begin{array}{l}\text { Listing all the attributes of all the alternatives and } \\
\text { letting people make trade-offs when necessary }\end{array}$ & $\begin{array}{l}\text { Online product configuration systems that make choices simpler by } \\
\text { guiding users through the purchase process }\end{array}$ \\
\hline
\end{tabular}

Table 2 Example applications of digital nudging and their effects

\begin{tabular}{lll}
\hline Use case/IS field & Nudging example/behavior change intervention & Effect on organizational or societal level \\
\hline $\begin{array}{l}\text { Business process management } \\
\text { E-business and e-commerce }\end{array}$ & $\begin{array}{l}\text { Structuring complex input screens } \\
\text { Displaying limited room inventory during a hotel-booking } \\
\text { process }\end{array}$ & $\begin{array}{l}\text { Organizational } \\
\text { Organizational }\end{array}$ \\
E-finance and insurance & Setting defaults for frequently selected insurance plan options & Societal \\
E-government & Setting defaults to opt in for organ donation & Societal \\
E-health & Step counter app that provides feedback on activity levels & Societal \\
E-learning & Reminder to learners to engage with course content & Organizational and/or societal \\
Green IS & Smart meters to encourage energy savings & Societal \\
Security and privacy & Displaying the strength of selected passwords & Organizational and/or societal \\
Social media & Giving incentives, such as badges, for sharing or other activities & Societal \\
\hline
\end{tabular}

Research on digital nudging is likely to evolve into an important area of design science research, as knowledge about the behavioral effects of interface-design decisions on users' behavior will provide valuable guidance for improved interface design. New design theories may evolve that extend knowledge from psychology and behavioral economics to digital choice environments. As research on digital nudging is still in its early stages, clarification of the theoretical mechanisms that underlie digital nudging is needed, as is the development of theoretically based design recommendations to inform research on persuasive technology (Fogg 2003), particularly the design of persuasive systems (Oinas-Kukkonen and Harjumaa 2009) like behavior-change support systems (OinasKukkonen 2010).

Because of the ubiquitous digitalization of our private and professional lives, digital nudging will soon extend to other application areas as people will use digital devices to make decisions in more situations and sectors, and the devices themselves will diversify in form and function. New devices will emerge with new interaction and interface design elements, such as kinetics, virtual reality, and holograms, and designers will need to understand the potential behavioral effects of these new technologies on people's judgment and decision-making.

We encourage our fellow scholars to engage in research on digital nudging, a fascinating area of information systems research that bears considerable potential for both research and society.

\section{Further Reading}

We suggest the following books for further reading on offline nudging and the underlying mechanisms: Kahneman 2011; Thaler and Sunstein 2008.

Open Access This article is distributed under the terms of the Creative Commons Attribution 4.0 International License (http://crea tivecommons.org/licenses/by/4.0/), which permits unrestricted use, distribution, and reproduction in any medium, provided you give appropriate credit to the original author(s) and the source, provide a link to the Creative Commons license, and indicate if changes were made. 


\section{References}

Carr A (2013) How square register's UI guilts you into leaving tips. http://www.fastcodesign.com/3022182/innovation-by-design/ how-square-registers-ui-guilts-you-into-leaving-tips. Accessed 08 Aug 2016

Dolan P, Hallsworth M, Halpern D, King D, Metcalfe R, Vlaev I (2012) Influencing behaviour: the mindspace way. J Econ Psychol 1(33):264-277

Evans JSBT (2006) The heuristic-analytic theory of reasoning: extension and evaluation. Psychon Bull Rev 3(13):378-395

Evans JSBT (2008) Dual-processing accounts of reasoning, judgment, and social cognition. Ann Rev Psychol 1(59):255-278

Fogg BJ (2003) Persuasive technology: using computers to change what we think and do. Elsevier, Oxford

Hutchinson JMC, Gigerenzer G (2005) Simple heuristics and rules of thumb: where psychologists and behavioural biologists might meet. Behav Process 2(69):97-124

Johnson EJ, Goldstein D (2003) Do defaults save lives? Science 5649(302):1338-1339

Johnson EJ, Shu SB, Dellaert BGC, Fox C, Goldstein DG, Häubl G, Larrick RP, Payne JW, Peters E, Schkade D, Wansink B, Weber EU (2012) Beyond nudges: tools of a choice architecture. Marketing Lett 2(23):487-504

Kahneman D (2011) Thinking, fast and slow. Farrar, Straus and Giroux, New York

Mandel N, Johnson EJ (2002) When web pages influence choice: effects of visual primes on experts and novices. J Consum Res 2(29):235-245
Michie S, Richardson M, Johnston M, Abraham C, Francis J, Hardeman W, Eccles MP, Cane J, Wood CE (2013) The behavior change technique taxonomy (v1) of 93 hierarchically clustered techniques: building an international consensus for the reporting of behavior change interventions. Ann Behav Med $1(46): 81-95$

Oinas-Kukkonen H (2010) Behavior change support systems: a research model and agenda. In: Ploug $\mathrm{T}$, Hasle $\mathrm{P}$, OinasKukkonen $\mathrm{H}$ (eds) Persuasive technology: lecture notes in computer science, vol 6137. Springer, Heidelberg, pp 4-14

Oinas-Kukkonen H, Harjumaa M (2009) Persuasive systems design: key issues, process model, and system features. Commun Assoc Inf Syst 28(24):485-500

Simon HA (1955) A behavioral model of rational choice. Q J Econ 1(69):99-118

Sunstein CR (2015) Nudging and choice architecture: ethical considerations. SSRN Electron J. http://papers.ssrn.com/sol3/ papers.cfm?abstract_id=2551264. Accessed 15 Mar 2016

Thaler RH, Sunstein CR (2008) Nudge: improving decisions about health, wealth, and happiness. Yale University Press, New Haven

Thaler RH, Sunstein CR, Balz JP (2010) Choice architecture. SSRN Electron J. http://papers.ssrn.com/sol3/papers.cfm?abstract_id= 1583509. Accessed 08 Aug 2016

Tversky A, Kahneman D (1974) Judgment under uncertainty: heuristics and biases. Science 4157(185):1124-1131 